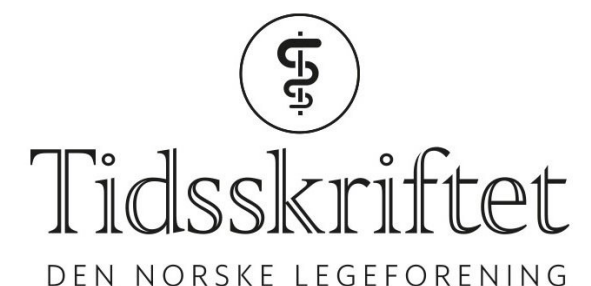

DEN NORSKE LEGEFORENING

\title{
Dødelige fritidsbåtulykker kan forebygges
}

DEBATT

\section{ERIK SVEBERG DIETRICHS}

E-post: erik.sveberg.dietrichs@uit.no

Erik Sveberg Dietrichs er ph.d. og lege ved Laboratoriemedisin, Universitetssykehuset Nord-Norge, samt førsteamanuensis og leder for forskningsgruppen Eksperimentell og klinisk farmakologi ved Universitetet i Troms $\emptyset$ - Norges arktiske universitet. Han sitter i styret i Foreningen for leger i vitenskapelige stillinger.

Forfatteren har fylt ut ICMJE-skjemaet og oppgir ingen interessekonflikter.

\section{MARIANNE ARNESTAD}

Marianne Arnestad er dr.med. og spesialist i klinisk farmakologi. Hun er seksjonsleder og overlege ved Avdeling for rettsmedisinske fag, Oslo universitetssykehus.

Forfatteren har fylt ut ICMJE-skjemaet og oppgir ingen interessekonflikter.

\section{JAN THORE MELLEM}

Jan Thore Mellem er klinisk psykolog og organisasjonspsykolog ved Statens havarikommisjon for transport.

Forfatteren har fylt ut ICMJE-skjemaet og oppgir ingen interessekonflikter.

\section{PÅL BRENNHOVD}

Pål Brennhovd er sivilingeniør og master i samfunn, vitenskap og teknologi. Han er havariinspektør i Statens havarikommisjon for transport (SHT) og ledet Havarikommisjonens arbeid med å kartlegge fritidsbåtulykker.

Forfatteren har fylt ut ICMJE-skjemaet og oppgir ingen interessekonflikter.

I 2018 omkom 23 personer i fritidsbåtulykker. Vi mener at mange av ulykkene kunne ha vært unngått.

Mellom 2008 og 2017 mistet 367 personer livet i fritidsbåtulykker. Statens havarikommisjon for transport (SHT) har med sakkyndig bistand kartlagt slike ulykker for å skaffe kunnskapsgrunnlag til å iverksette effektive forebyggende tiltak (1). Ut fra kartleggingen fremkommer det at det i 2018 var 22 fatale fritidsbåtulykker. Totalt 44 personer var involvert i disse ulykkene, hvorav 23 omkom og 3 fikk alvorlige skader. Disse tallene er lavere enn for tidligere år.

\section{Grunnstøtinger og kollisjoner}

Hver femte forulykkede i 2018 omkom da båten gikk på grunn eller kolliderte. Disse ulykkene kjennetegnes av tre faktorer: høy fart (> 20 knop), ruspåvirkning og tussmørke. Alle de involverte var yngre enn 45 år, og tre var tenåringer. Grunnstøtingene og 
kollisjonene oppstod på vei hjem fra uteliv. Førerne var båtvante og kjent i farvannet. De omkomne ble hovedsakelig påført traumatiske hodeskader. Disse skadene var enten direkte dødsårsak eller til hinder for selvberging og dermed årsak til drukning. Hverken førere eller passasjerer rakk å reagere før ulykkene inntraff.

Fem av seks båtførere var ruspåvirket, med gjennomsnittlig promille på 1,4. Rusnivået tilsvarer det som har blitt observert blant ruspåvirkede bilførere som omkommer (2).

Ulykkene kjennetegnes av tre faktorer: høy fart, ruspåvirkning og tussmørke

Promillegrensen for båt med lengde under 15 meter er o,8 - altså fire ganger høyere enn for bil. Det er individuelle forskjeller på alkoholinntakets virkning på bedømmelsesevne, stemningsleie, konsentrasjons- og reaksjonsevne, sjansetaking og aggressivitet, men alle effektene er avhengige av etanolkonsentrasjonen i blodet $(1,3)$. Ved promille på 0,8 tyder mer enn $94 \%$ av publiserte studier på en svekkelse av kjøreferdigheter i bil (4). Erfaringene fra veitrafikk viser at reduksjon av promillegrensen til o,2 kan ha positive resultater ved at det blir færre personskader og dødsulykker. Strengere promillegrense gir likevel ingen reduksjon av ulykker uten samtidig intensivering av promillekontroll (5).

\section{Kantringsulykker og fall over bord}

Halvparten av de forulykkede i 2018 var involvert i kantringsulykker og fall over bord, og omkom i hovedsak av drukning. Forutsatt at flyteevne og frie luftveier har vært beholdt etter at personene falt i vannet, har nedkjøling sannsynligvis bidratt til drukningen.

Et sentralt fellestrekk for disse ulykkene var at det tok lang tid (> 45 minutter) før andre ble klar over at noen var i nød. De forulykkede fikk som oftest ikke varslet med mobiltelefon, og andre varslingsmåter (fløyte, nødbluss, håndholdt VHF-radio, nødpeilesender eller AISsender) var sjelden tilgjengelige. De omkomne var kledd for å være om bord i båten, men ikke for å ligge i sjøen. Flytemiddel ble ikke brukt, ble ikke brukt korrekt eller sørget ikke for frie luftveier. Ingen av de omkomne brukte tørrdrakt. Med ett unntak var denne gruppen omkomne ikke ruspåvirket (1).

Nedkjøling beskytter hjernen mot oksygenmangel. Frie luftveier under nedkjøling til hypoterm hjertestans gir derfor større mulighet for vellykket gjenopplivning (6). Vårt begrensede datamateriale indikerer at unge mennesker har bedre overlevelsesevne enn eldre etter fall i kaldt vann (1). Utfallet etter ulykken i Præstø Fjord i Danmark underbygger denne observasjonen. Syv ungdommer ble funnet med hjertestans i fjorden, mer enn halvannen time etter ulykken. Alle ble gjenopplivet, mens én lærer omkom (7).

\section{Fall mellom fortøyd båt og brygge}

Denne gruppen utgjorde en femtedel av alle dødsulykkene og var sterkt knyttet til bruk av alkohol. Ulykkene skjedde om natten og rammet mennesker som var eldre enn 50 år. De omkomne var tydelig ruspåvirket, med en gjennomsnittlig promille på 2,3. Personene brukte hovedsakelig ikke flytemiddel, og samtlige druknet.

\section{Antall omkomne kan reduseres}

Det er nærliggende å tro at antall omkomne etter fall over bord og kantringsulykker kan reduseres ved tidlig varsling om nød og posisjon, riktig bruk av flytemiddel og bruk av påkledning som forsinker nedkjøling. Vi finner at det er et stort behov for videre forskning på sammenhengene mellom personskader ved båtulykker og ulike risikofaktorer som alkohol- og medisinbruk og psykisk og fysisk helse, slik at forebyggende tiltak kan iverksettes. 
1. Kartlegging av fritidsbåtulykker. Lillestrøm: Statens Havarikommisjon for Transport, 2019.

2. Gjerde H, Christophersen AS. Ruspåvirkning blant bilførere som omkom i trafikkulykker i 2001-10. Oslo: Folkehelseinstituttet, 2012.

3. Mørland J et al. Biologiske virkningsmekanismer og noen kliniske effekter av alkohol. Tidsskr Nor Lægeforen 2003; 123: 180-4.

4. Moskowitz H, Fiorentino D. A Review of the Literature on the Effects of Low Doses of Alcohol on Driving-Related Skills. Washington: National Highway Traffic Safety Administration, 2000.

5. Haghpanahan H, Lewsey J, Mackay DF et al. An evaluation of the effects of lowering blood alcohol concentration limits for drivers on the rates of road traffic accidents and alcohol consumption: a natural experiment. Lancet 2019; Jan; 393(10169):321-9. [PubMed][CrossRef]

6. Dietrichs E, Dietrichs ES et al. Nevroprotektiv effekt av hypotermi. Tidsskr Nor Legeforen 2015; 135: 1646-51.

7. Wanscher M, Agersnap L, Ravn J et al. Outcome of accidental hypothermia with or without circulatory arrest: experience from the Danish Præstø Fjord boating accident. Resuscitation 2012; 83: 1078-84. [PubMed][CrossRef]

Publisert: 8. juli 2019. Tidsskr Nor Legeforen. DOI: 10.4045/tidsskr.19.0366

Mottatt 23.5.2019, første revisjon innsendt 17.6.2019, godkjent 18.6.2019.

(C) Tidsskrift for Den norske legeforening 2020. Lastet ned fra tidsskriftet.no 